\title{
Anion Binding to Monotopic and Ditopic Macrocyclic Amides.
}

\author{
Ivan V. Korendovych, ${ }^{\mathrm{a}}$ Mimi Cho, ${ }^{\text {a }}$ Phillip L. Butler, ${ }^{\mathrm{a}}$ Richard J. Staples, ${ }^{\mathrm{b}}$ Elena V. \\ Rybak-Akimova ${ }^{*, a}$ \\ ${ }^{a}$ Department of Chemistry, Tufts University, 62 Talbot Ave., Medford, MA 02155 \\ ${ }^{b}$ Department of Chemistry and Chemical Biology, Harvard University, 12 Oxford St., Cambridge, MA \\ 02138
}

General. ${ }^{1} \mathrm{H}(300.35 \mathrm{MHz})$ and ${ }^{13} \mathrm{C}(75.53 \mathrm{MHz})$ NMR spectra were recorded on a Bruker DPX-300 spectrometer and referenced to the residual solvent peak $\left({ }^{1} \mathrm{H}\right.$ $\delta\left(\mathrm{CHCl}_{3}\right)=7.27 \mathrm{ppm}, \delta\left(\left(\mathrm{CHD}_{2} \mathrm{~S}(\mathrm{O}) \mathrm{CH}_{3}\right)=2.50 \mathrm{ppm}\right)$ or to the solvent peak $\left({ }^{13} \mathrm{C}\right.$ $\left.\delta\left(\mathrm{CDCl}_{3}\right)=77.23 \mathrm{ppm}, \delta\left(\left(\mathrm{CD}_{3}\right)_{2} \mathrm{SO}\right)=39.51 \mathrm{ppm}\right) .{ }^{19} \mathrm{~F}$ NMR spectra were referenced to an external standard $\left(\delta\left(\mathrm{CF}_{3} \mathrm{CO}_{2} \mathrm{H}\right)\right.$ in $\left(\mathrm{CD}_{3}\right)_{2} \mathrm{SO}$ was assumed to be $\left.-76.55 \mathrm{ppm}\right)$. Anion binding to macrocyclic ligands was studied by ${ }^{1} \mathrm{H}$ NMR titrations. $0.500 \mathrm{~mL}$ of $10 \mathrm{mM}$ solution of macrocyclic ligand in $\mathrm{d}_{6}$-DMSO was placed in an NMR tube. Aliquots of 100 $\mathrm{mM}$ solution of titrant were added and spectra were recorded. Binding curves were fit using program Wineqnmr. ${ }^{1}$ The quality of fit was estimated using the 'merit-function' shown in equation (1) where $\mathrm{W}_{\mathrm{i}}$ is the weight attributed to observation $\mathrm{i}$ (normally data points were assigned equal weights):

$$
R=100\left(\frac{\sum \mathrm{W}_{\mathrm{i}}\left(\delta_{\mathrm{obs}}-\delta_{\mathrm{calc}}\right)^{2}}{\sum W_{i}\left(\delta_{\mathrm{obs}}\right)^{2}}\right)^{\frac{1}{2}}
$$

Electrospray mass spectrometry was performed on a Finnigan LTQ instrument. Samples for Job's plots were prepared by first mixing $250 \mu \mathrm{L}$ of a $10 \mathrm{mM}$ solution of the macrocycle with $250 \mu \mathrm{L}$ of a $10 \mathrm{mM}$ solution of the guest. The exact concentrations of the guest and host macrocycle solutions were determined from this 
experiment and then used for calculating volumes of the macrocyclic host and the guest solutions, so that the total number of moles was constant for all experiments.

X-ray diffractometry. Data were collected using a Bruker SMART CCD (charge coupled device) based diffractometer. A suitable crystal was chosen and mounted on a glass fiber using Paratone-N oil. Data were measured using omega scans of $0.3^{\circ}$ per frame for 30 seconds, such that a hemisphere was collected. A total of 1650 frames for 2b, 4.2MeOH and 4.2DMSO, and a total of 1271 frames for $\mathbf{2 a}$ were collected with a maximum resolution of $0.75 \AA$. The first 50 frames were recollected at the end of data collection to monitor for decay. Cell parameters were retrieved using SMART ${ }^{2}$ software and refined using SAINT on all observed reflections. Data reduction was performed using the SAINT software ${ }^{3}$ which corrects for Lp.

The structures were solved by the direct method using the SHELXS-97 $7^{4}$ program and refined by least squares method on $\mathrm{F}^{2}$, SHELXL-97, ${ }^{5}$ incorporated in SHELXTL V5.10. ${ }^{6}$ The structures of $\mathbf{4} \cdot \mathbf{2 M e O H}$ and $\mathbf{4} \cdot \mathbf{2 D M S O}$ were solved in the space group P -1 (\#2) for by analysis of systematic absences. All non-hydrogen atoms are refined anisotropically. Hydrogen atoms were calculated by geometrical methods and refined as a riding model. All drawings are done at $50 \%$ ellipsoids. In all cases the compound lies on an inversion center.

For $\mathbf{2 b}$, the structure was solved in the space group $\mathrm{P} 2{ }_{1} / \mathrm{c}$ (\# 15) by analysis of systematic absences. All non-hydrogen atoms are refined anisotropically. Hydrogen atoms were located on a Fourier difference map and refined isotropically.

For 2a, the structure was solved in the space group Pcab (\# 61) by analysis of systematic absences. All non-hydrogen atoms are refined anisotropically. Hydrogen atoms were calculated by geometrical methods and refined as a riding model. The crystals used for the diffraction study showed no decomposition during data collection.

Materials All materials used were ACS reagent grade or better and were used without additional purification. 2,6-pyridinedicarboxylic acid and anhydrous dimethylsulfoxide were purchased from Acros. All other reagents were purchased from Aldrich. 2,6 -pyridinedicarboxylic acid dimethyl ester, ${ }^{7} \mathrm{H}_{2} \mathrm{PyDioneN}_{5}(\mathbf{1})^{8}$ and $\mathbf{2} \mathbf{b}^{9}$ were synthesized according to previously reported procedures. 1,4,7,10-tetraazadecane and 
1,5,9-triazanonane were dried over $\mathrm{KOH}$ at $60{ }^{\circ} \mathrm{C}$ and were distilled over sodium prior to use.

\section{Syntheses}

\section{3,7,11,17-Tetraazabicyclo[11.3.1]heptadeca-1(17),13,15-triene-2,12-dione (2a)}

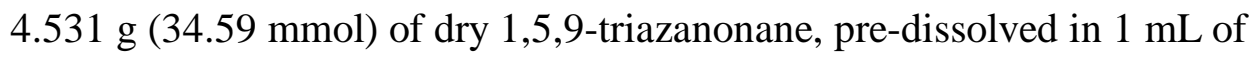
methanol was added to the solution of $6.745 \mathrm{~g}(34.59 \mathrm{mmol})$ of 2,6-pyridine dicarboxylic acid dimethyl ester in $500 \mathrm{~mL}$ of methanol. The resulting reaction mixture was allowed to reflux overnight.

After refluxing, the reaction mixture was concentrated to about $250 \mathrm{~mL}$ in vacuo and it was left for 2 days at room temperature in order to allow the product of the [2+2] condensation to precipitate out from the mixture. The [2+2] condensation was removed by filtration. The solvent was removed from the filtrate in vacuo to produce a mixture of white solid and brownish oil. 2a was isolated from the crude mixture by column chromatography on silica using 5\% methanol- chloroform mixture as eluent. Mass spectrometry was used to analyze the column fractions. Yield $0.26 \mathrm{~g} \mathrm{(3 \% ).}$

${ }^{1} \mathrm{H}$ NMR (300 MHz, d 6 -DMSO) $\delta 10.08$ (t, $\left.J=5 \mathrm{~Hz} 2 \mathrm{H},-\mathrm{C}(\mathrm{O}) \mathrm{N} H-\right), 8.19$ (d, $J=$ $7.7 \mathrm{~Hz}, 2 \mathrm{H}, \beta-\mathrm{H}$ of the pyridine ring), $8.03(\mathrm{t}, J=7.6 \mathrm{~Hz}, 1 \mathrm{H}, \gamma-\mathrm{H}$ of the pyridine ring), 3.59 (q, $\left.J=5.4 \mathrm{~Hz}, 4 \mathrm{H},-\mathrm{C}(\mathrm{O}) \mathrm{NHCH}_{2}-\right), 2.97\left(\mathrm{t}, J=4.6 \mathrm{~Hz}, 4 \mathrm{H},-\mathrm{C}(\mathrm{O}) \mathrm{NHCH}_{2} \mathrm{CH}_{2} \mathrm{CH}_{2^{-}}\right.$), 1.92 (quintet, $J=5.3 \mathrm{~Hz}, 4 \mathrm{H},-\mathrm{C}(\mathrm{O}) \mathrm{NHCH}_{2} \mathrm{CH}_{2}$ ). MS (ESI), $m / z: 263.18$ (100\%, $\left.[\mathrm{M}+\mathrm{H}]^{+}\right)$.

Product of [2+1] addition (3). $3.66 \mathrm{~g}$ (25 mmol) of 1,4,7,10-tetraazadecane dissolved in $75 \mathrm{~mL}$ of methanol was slowly added (in 2 hours) dropwise to $30.12 \mathrm{~g}$ (154 mmol) of the 2,6 -pyridinedicarboxylic acid dimethyl ester dissolved in $250 \mathrm{~mL}$ at reflux. Upon addition the reaction mixture was allowed to reflux overnight. Afterward the reaction mixture was cooled down to room temperature and concentrated to ca. $100 \mathrm{~mL}$ in vacuo. Precipitated excess diester was filtered off. The solvent from the filtrate was removed in vacuo to yield creamy white solid that was subjected to column chromatography on silica (gradient elution $10 \% \mathrm{v}$. $\mathrm{MeOH}-\mathrm{CHCl}_{3}$ to $20 \% \mathrm{v}$. $\mathrm{MeOH}-$ $\left.\mathrm{CHCl}_{3}\right)$ to produce $3.55 \mathrm{~g} \mathrm{(30 \% )}$ of $\mathbf{3}$ as white solid. 
${ }^{1} \mathrm{H}$ NMR $\left(300 \mathrm{MHz}, \mathrm{CDCl}_{3}\right) \delta 8.50$ (t, J=5.3 Hz, 2H, $-\mathrm{C}(\mathrm{O}) \mathrm{NH}$-), 8.35 (d.d., J=6.7Hz, $1 \mathrm{~Hz}, 2 \mathrm{H}, \beta-\mathrm{H}$ ), 8.17 (d.d., J=6.7Hz, 1Hz, 2H, $\beta$-H), 7.97 (t, J=7.8 Hz, 2H, $\gamma-\mathrm{H}$ ), 4.00 (s, $6 \mathrm{H}-\mathrm{OCH}_{3}$ ), 3.60 (q, J=6.0 Hz obs., 4H, $\left.-\mathrm{C}(\mathrm{O}) \mathrm{NHCH}_{2}-\right), 2.93$ (t, J=6.0 Hz, 4H, $-\mathrm{C}(\mathrm{O}) \mathrm{NHCH}_{2} \mathrm{CH}_{2}$ ), 2.83 (s, 4H, - $\left.\mathrm{CH}_{2} \mathrm{NHCH}_{2} \mathrm{CH}_{2} \mathrm{NHCH}_{2}-\right) .{ }^{13} \mathrm{C} \mathrm{NMR}\left(75 \mathrm{MHz}, \mathrm{CDCl}_{3}\right.$ ) $\delta 165.1,163.9,150.5,146.6,138.6,127.3,125.5,53.1,48.9,48.7,39.5$. MS (ESI): 473.3 $(100 \%, \mathrm{M}+\mathrm{H})^{+}$.

Macrocycle (4). To $2.50 \mathrm{~g}$ (5.3 mmol) of $\mathbf{3}$ dissolved in $400 \mathrm{~mL}$ of methanol, $0.77 \mathrm{~g}(5.3 \mathrm{mmol})$ of the 1,4,7,10-tetraazadecane dissolved in $100 \mathrm{~mL}$ of methanol was quickly added. The reaction mixture was then refluxed for 24 hours. Afterward the reaction mixture was concentrated to $75 \mathrm{~mL}$. $4 \cdot 2 \mathrm{MeOH}$ slowly precipitated within several days and was collected by filtration. Yield $0.95 \mathrm{~g}$ (32\%).

${ }^{1} \mathrm{H}$ NMR $\left(300 \mathrm{MHz}, \mathrm{CDCl}_{3}\right) \delta 8.82(\mathrm{t}, \mathrm{J}=5.5 \mathrm{~Hz}, 2 \mathrm{H},-\mathrm{C}(\mathrm{O}) \mathrm{NH}-), 8.32(\mathrm{~d} ., \mathrm{J}=7.8 \mathrm{~Hz}, 2 \mathrm{H}$, $\beta$-H), 8.01 (t, J=7.8 Hz, 1H, $\gamma-\mathrm{H}$ ), 3.61 (q, J=5.7 Hz obs., 4H, $-\mathrm{C}(\mathrm{O}) \mathrm{NHCH}_{2^{-}}$), 3.45 (s, $3 \mathrm{H}$ bound $\left.\mathrm{HOCH}_{3}\right), 2.90$ (t, J=5.4 Hz, 4H, $\left.-\mathrm{C}(\mathrm{O}) \mathrm{NHCH}_{2} \mathrm{CH}_{2}-\right), 2.84$ (s, 4H, $-\mathrm{CH}_{2} \mathrm{NHCH}_{2} \mathrm{CH}_{2} \mathrm{NHCH}_{2}$ ). ${ }^{13} \mathrm{C} \mathrm{NMR}\left(75 \mathrm{MHz}, \mathrm{CDCl}_{3}\right) \delta 164.0,149.0,139.1,125.0$, 50.4, 48.9, 48.7, 39.2. MS (ESI): $555.45(100 \%, \mathrm{M}+\mathrm{H})^{+}$.

The DMSO adduct of $4(4 \cdot 2 \mathrm{DMSO})$ can be obtained by crystallization of $4 \cdot 2 \mathrm{MeOH}$ from DMSO. Upon standing in dichloromethane solution, $4 \cdot 2 \mathrm{MeOH}$ loses methanol to precipitate as white solid. ${ }^{1} \mathrm{H}$ NMR $\left(300 \mathrm{MHz},\left(\mathrm{CD}_{3}\right)_{2} \mathrm{SO}\right) \delta 9.27(\mathrm{t}, \mathrm{J}=6.0 \mathrm{~Hz}, 2 \mathrm{H}$, $\mathrm{C}(\mathrm{O}) \mathrm{NH}-$ ) , 8.25-8.10 (m., $3 \mathrm{H}, \beta, \gamma \mathrm{H}$ of the pyridine ring ), 3.43 (q, $\mathrm{J}=6.1 \mathrm{~Hz}$ obs., $4 \mathrm{H}$, $\left.-\mathrm{C}(\mathrm{O}) \mathrm{NHCH}_{2^{-}}\right), 2.71\left(\mathrm{t}, \mathrm{J}=6.3 \mathrm{~Hz}, 4 \mathrm{H},-\mathrm{C}(\mathrm{O}) \mathrm{NHCH}_{2} \mathrm{CH}_{2^{-}}\right), 2.64(\mathrm{~s}, 4 \mathrm{H}$, $\left.-\mathrm{CH}_{2} \mathrm{NHCH}_{2} \mathrm{CH}_{2} \mathrm{NHCH}_{2^{-}}\right) .{ }^{13} \mathrm{C} \mathrm{NMR}\left(75 \mathrm{MHz}, \mathrm{CDCl}_{3}\right) \delta 164.0,149.0,139.1,125.0$, $50.4,48.9,48.7,39.2$.

\section{Acknowledgement}

The CCD based X-ray diffractometer at Harvard University was purchased through NIH grant (1S10RR11937-01). The CCD based X-ray diffractometer at Tufts University was purchased through Air Force DURIP Grant F49620-01-1-0242.

\section{References}


1. Hynes, M. J., J. Chem. Soc., Dalton Trans. 1993, 311-312.

2. SMART V 5.054 (NT) Software for the CCD Detector System; Bruker Analytical X-ray Systems, Madison, WI (1998).

3. SAINT V 6.02 (NT) Software for the CCD Detector System Bruker Analytical Xray Systems, Madison, WI (2000).

4. Sheldrick, G. M. SHELXS-90, Program for the Solution of Crystal Structure, University of Göttingen, Germany, 1990.

5. Sheldrick, G. M. SHELXL-97, Program for the Refinement of Crystal Structure, University of Göttingen, Germany, 1997.

6. SHELXTL 6.10 (PC/NT-Version), Program library for Structure Solution and Molecular Graphics; Bruker Analytical X-ray Systems, Madison, WI (2000).

7. Dierck, I.; Herman, G. G.; Goeminne, A. M.; Van der kelen, G. P., Bull. Soc. Chim. Belg. 1993, 102, (1), 63-66.

8. Korendovych, I. V.; Staples, R. J.; Reiff, W. M.; Rybak-Akimova, E. V., Inorg. Chem. 2004, 43, 3930-3941.

9. Voegtle, F.; Weber, E.; Wehner, W.; Naetscher, R.; Gruetze, J., Chemiker-Zeitung 1974, 98, 562-563.

10. Chmielewski, M. J.; Jurczak, J., Chem. Eur. J. 2005, 11, 6080-6094. 
Table 1. Crystallographic data for $2 \mathrm{a}, 2 \mathrm{~b}, 4 \cdot 2 \mathrm{MeOH}, 4 \cdot 2 \mathrm{DMSO}$.

\begin{tabular}{|c|c|c|c|c|}
\hline $\begin{array}{l}\text { chemical } \\
\text { formula }\end{array}$ & $\begin{array}{l}\mathrm{C}_{14} \mathrm{H}_{22} \mathrm{~N}_{4} \mathrm{O}_{3} \\
(\mathbf{2 a} \cdot \mathbf{M e O H})\end{array}$ & $\begin{array}{c}\mathrm{C}_{14} \mathrm{H}_{20} \mathrm{~N}_{4} \mathrm{O}_{2} \\
\text { (2b) }\end{array}$ & $\begin{array}{l}\mathrm{C}_{28} \mathrm{H}_{46} \mathrm{~N}_{10} \mathrm{O}_{6} \\
\text { (4.2MeOH) }\end{array}$ & $\begin{array}{c}\mathrm{C}_{34} \mathrm{H}_{62} \mathrm{~N}_{10} \mathrm{O}_{8} \mathrm{~S}_{4} \\
(\mathbf{4} \cdot \mathbf{2 D M S O})\end{array}$ \\
\hline Formula weight & 294.36 & 276.34 & 618.75 & 867.18 \\
\hline space group & Pcab & $\mathrm{P} 2_{1} / \mathrm{c}$ & P-1 & $\mathrm{P}-1$ \\
\hline$a, \AA$ & $7.046(4)$ & $6.0458(13)$ & $9.1721(7)$ & $10.2709(6)$ \\
\hline$b, \AA$ & $15.999(10)$ & 19.101(4) & $9.4004(7)$ & $10.8236(6)$ \\
\hline$c, \AA$ & $26.916(16)$ & $12.283(2)$ & $10.7902(8)$ & $11.1705(7)$ \\
\hline$\alpha, \operatorname{deg}$ & 90 & 90 & $102.0700(10)$ & $65.7600(10)$ \\
\hline$\beta, \operatorname{deg}$ & 90 & 104.201(4) & $115.0170(10)$ & $88.0310(10)$ \\
\hline$\gamma, \operatorname{deg}$ & 90 & 90 & $92.1090(10)$ & $78.3450(10)$ \\
\hline $\mathrm{V}, \AA^{3}$ & 3034(3) & 1375.1(5) & $816.15(11)$ & $1107.33(11)$ \\
\hline$Z$ & 8 & 4 & 1 & 1 \\
\hline$T, \mathrm{~K}$ & $213(2)$ & $173(2)$ & $303(2)$ & $213(2)$ \\
\hline$\lambda, \AA$ & 0.71073 & 0.71073 & 0.71073 & 0.71073 \\
\hline$D_{\text {calcd }}, \mathrm{g} \mathrm{cm}^{-3}$ & 1.289 & 1.335 & 1.259 & 1.300 \\
\hline$\mu, \mathrm{mm}^{-1}$ & 0.092 & 0.092 & 0.091 & 0.272 \\
\hline $\begin{array}{l}\text { Final } R \text { indices } \\
{[\mathrm{I}>2 \sigma(\mathrm{I})]}\end{array}$ & $\begin{array}{l}R=0.1479 \\
w R_{2}=0.3331\end{array}$ & $\begin{array}{l}R=0.0573 \\
w R_{2}=0.1363\end{array}$ & $\begin{array}{l}R=0.0489 \\
w R_{2}=0.1322\end{array}$ & $\begin{array}{l}R=0.0425 \\
w R_{2}=0.1127\end{array}$ \\
\hline $\begin{array}{l}\text { Final } \mathrm{R} \text { indices } \\
\text { [for all data] }\end{array}$ & $\begin{array}{l}R=0.1536 \\
w R_{2}=0.3383\end{array}$ & $\begin{array}{l}R=0.1567 \\
w R_{2}=0.1667\end{array}$ & $\begin{array}{l}R=0.590 \\
w R_{2}=0.1443\end{array}$ & $\begin{array}{l}R=0.0511 \\
w R_{2}=0.1157\end{array}$ \\
\hline
\end{tabular}




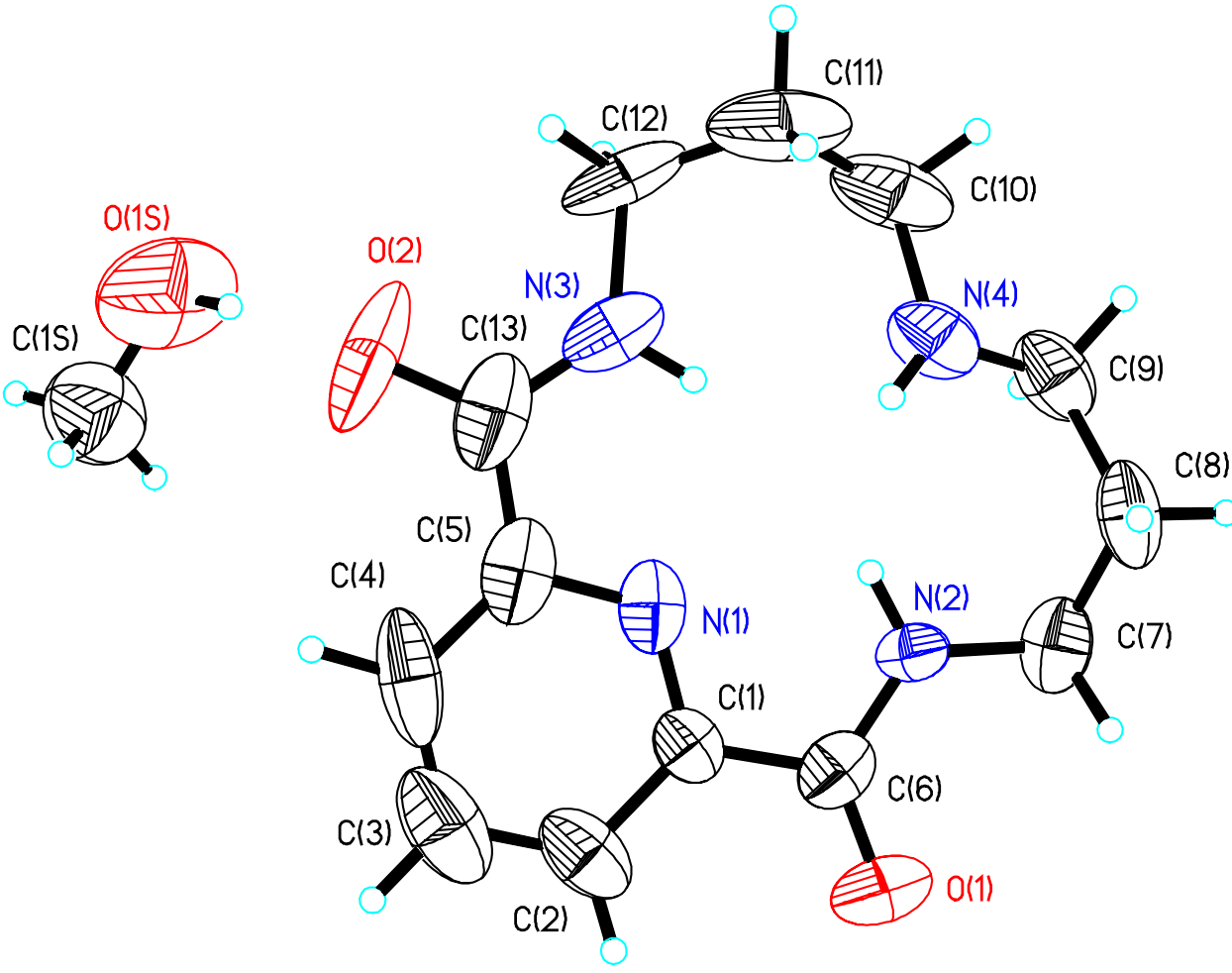

Figure S1. ORTEP plot of molecule of 2a. Displacement ellipsoids are drawn at the $50 \%$ probability level. 


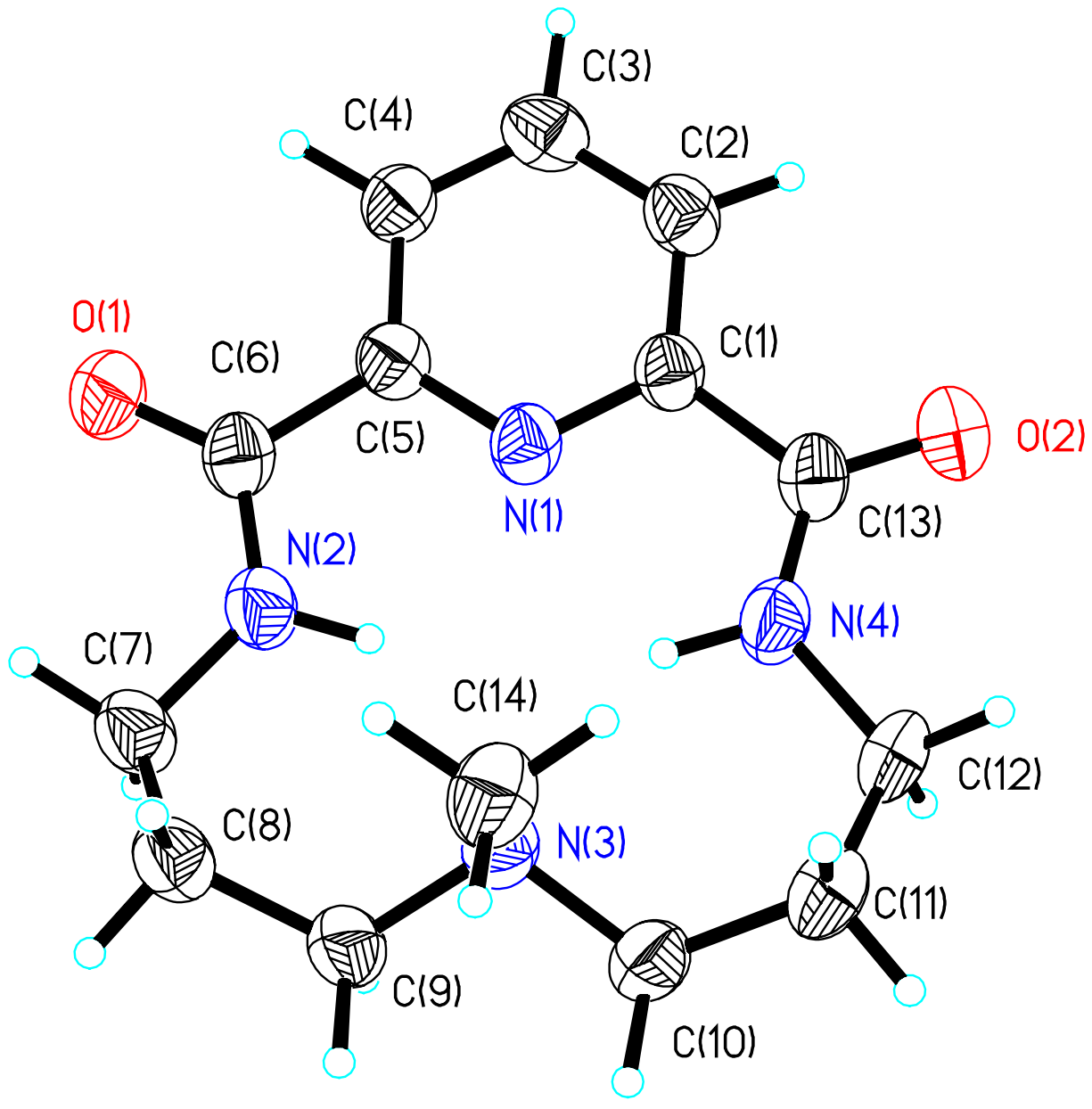

Figure S2. ORTEP plot of molecule of $2 \mathrm{~b}$. Displacement ellipsoids are drawn at the $50 \%$ probability level. 


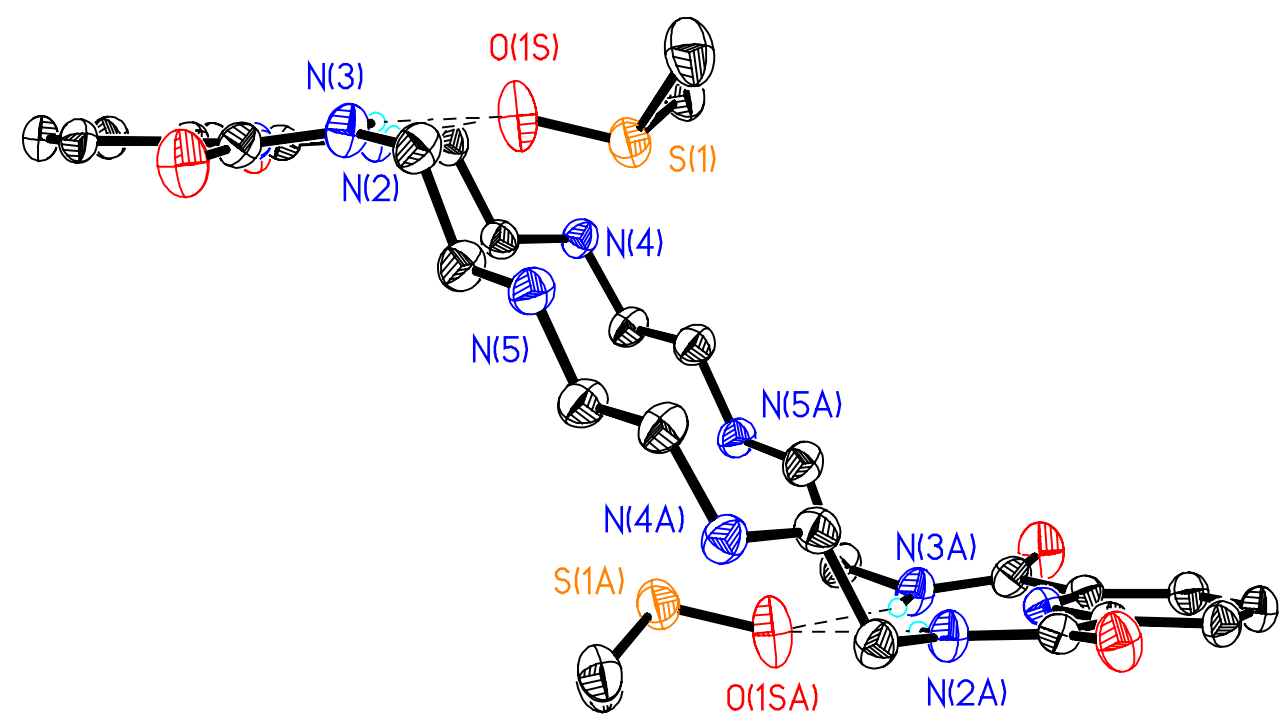

Figure S3. ORTEP plot of molecule of 4-2DMSO. Displacement ellipsoids are drawn at the 50\% probability level. 


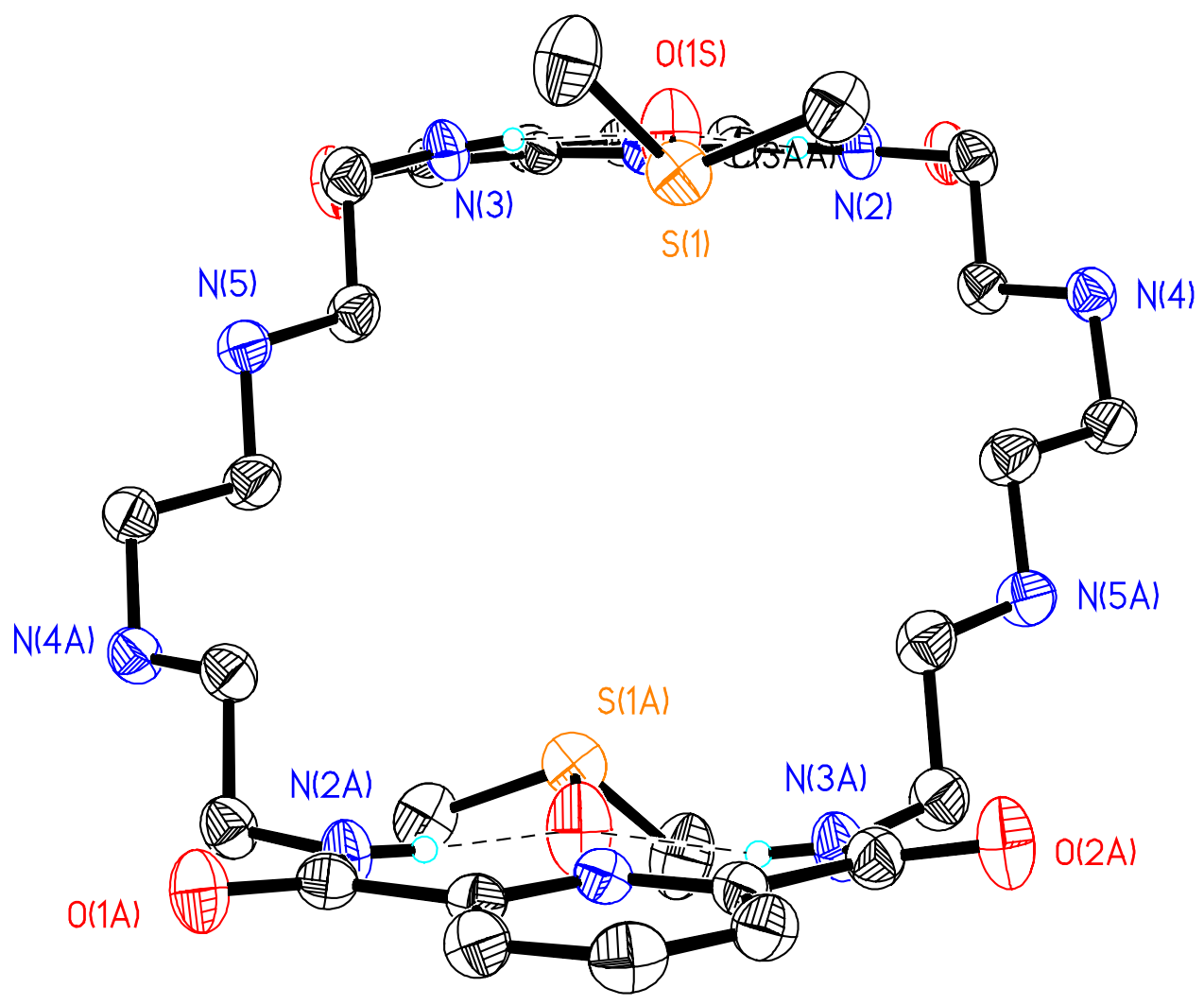

Figure S4. ORTEP plot of molecule of 4-2DMSO. Displacement ellipsoids are drawn at the 50\% probability level. 


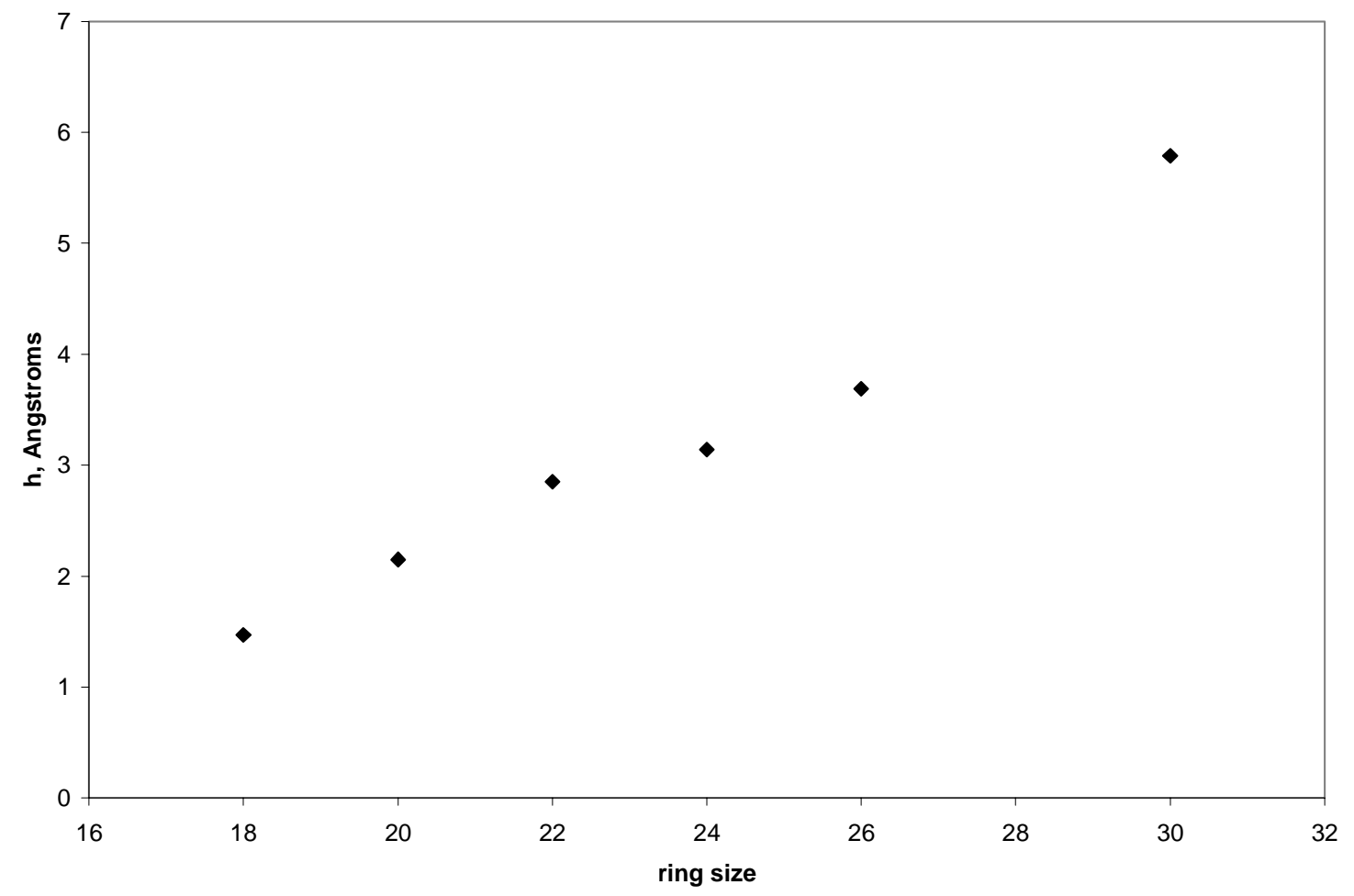

Figure S5. Dependence of the distance between the planes of the pyridine rings $(\mathrm{h})$ in the products of $[2+2]$ addition. Data for 18-26 membered rings is taken from ref. 10. The data for the 30-membered ring relates to $4 \cdot 2 \mathrm{DMSO}$. 


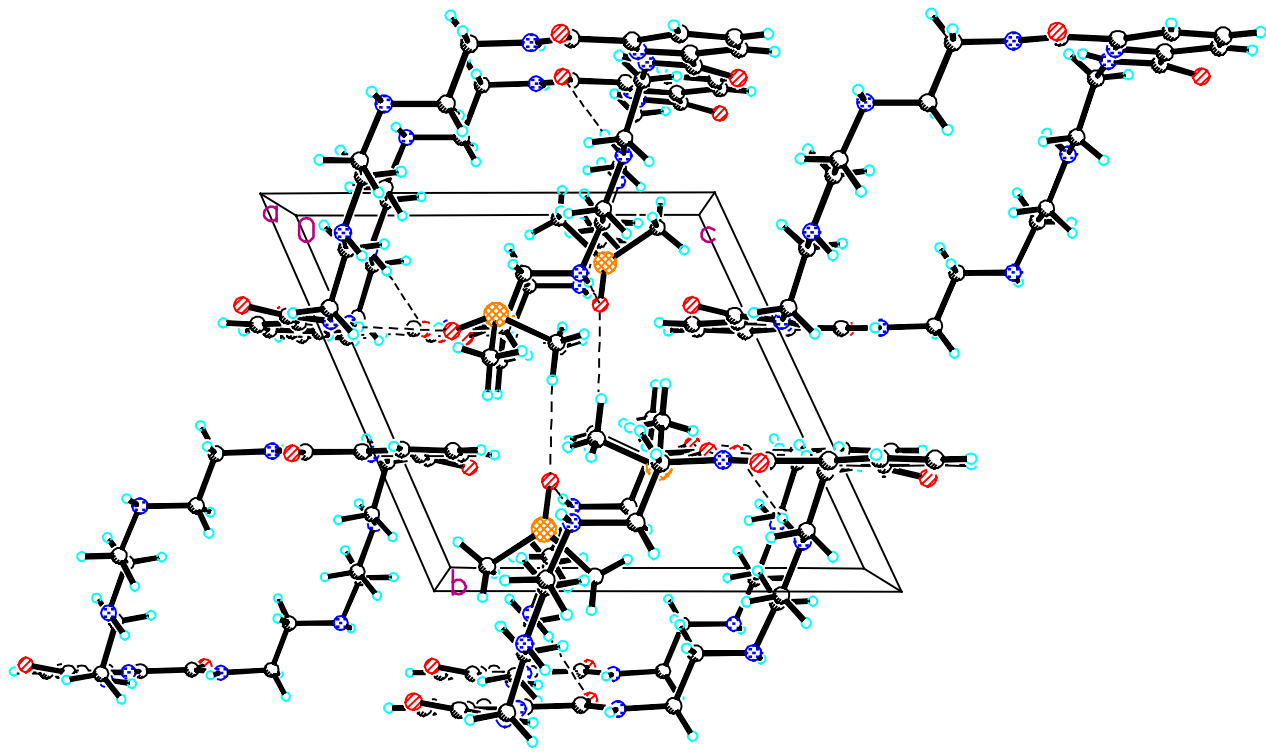

Figure S6. Packing diagram of 4-2DMSO viewed along the crystallographic a axis showing intermolecular hydrogen bonding. Displacement ellipsoids are drawn at the $50 \%$ probability level. 


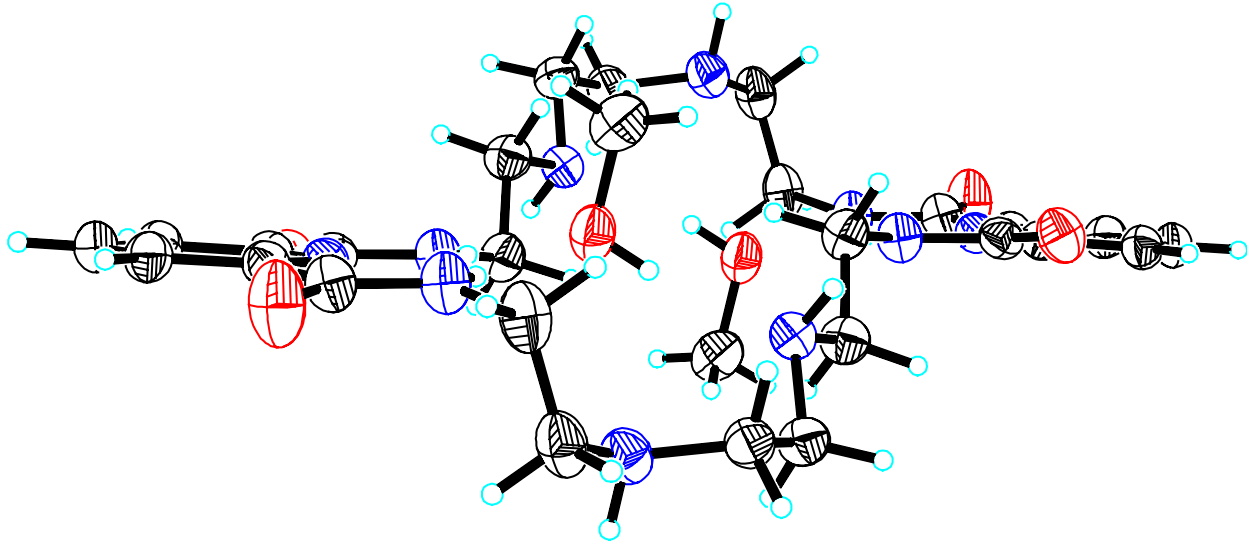

Figure S7. ORTEP plot of molecule of 4.2MeOH. Displacement ellipsoids are drawn at the $50 \%$ probability level. 


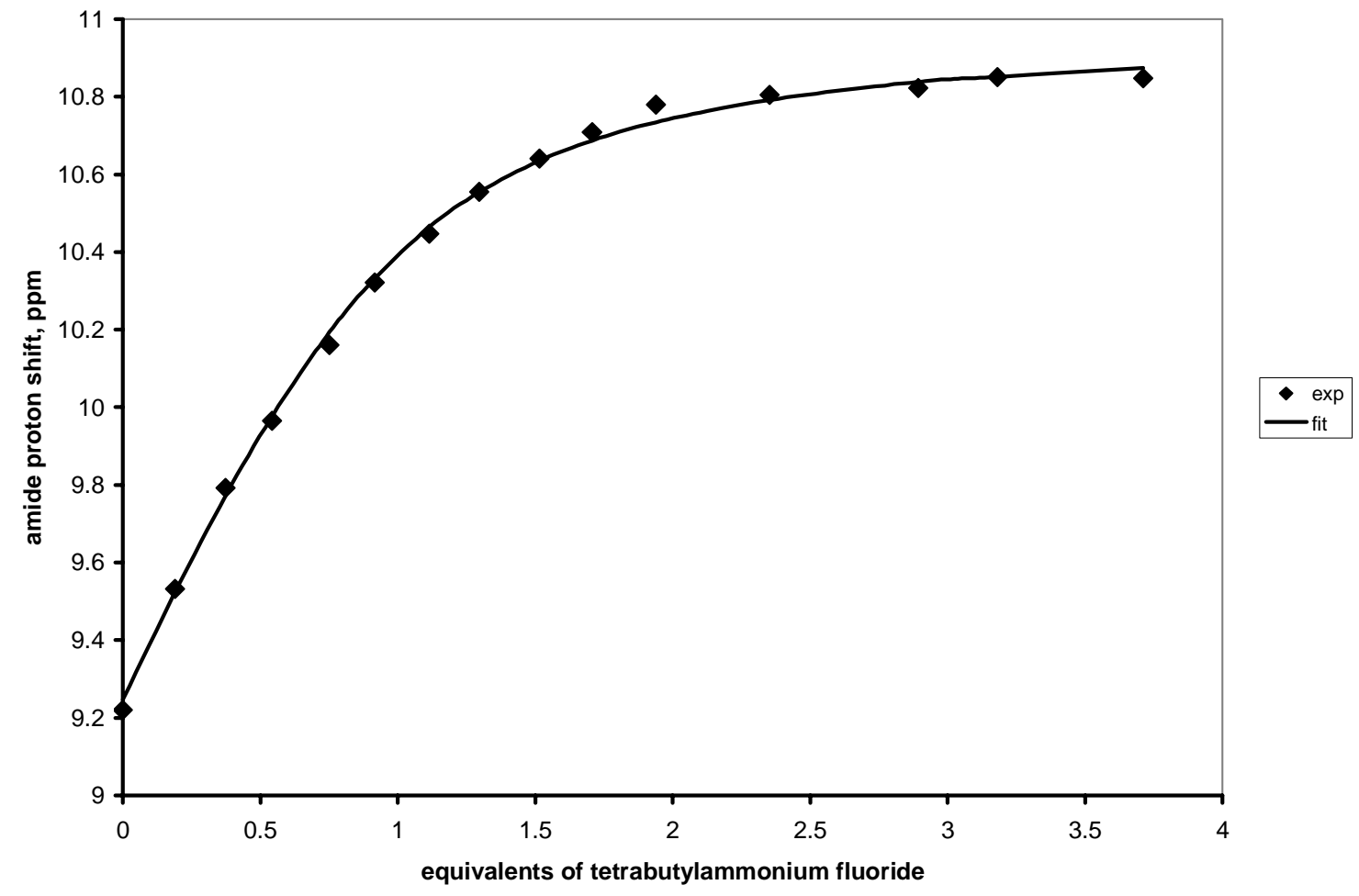

Figure S8. Titration curve of 1 with tetrabutylammonium fluoride. Binding parameters determined by program WinEQNMR are $\delta(1)=9.25(2) \mathrm{ppm}, \delta\left(1 \cdot \mathrm{F}^{-}\right)=11.01(3) \mathrm{ppm}$, association constant $\mathrm{K}=$ $5.8(7) \cdot 10^{2} \mathrm{M}^{-1}, \mathrm{R}=0.2 \%$. 


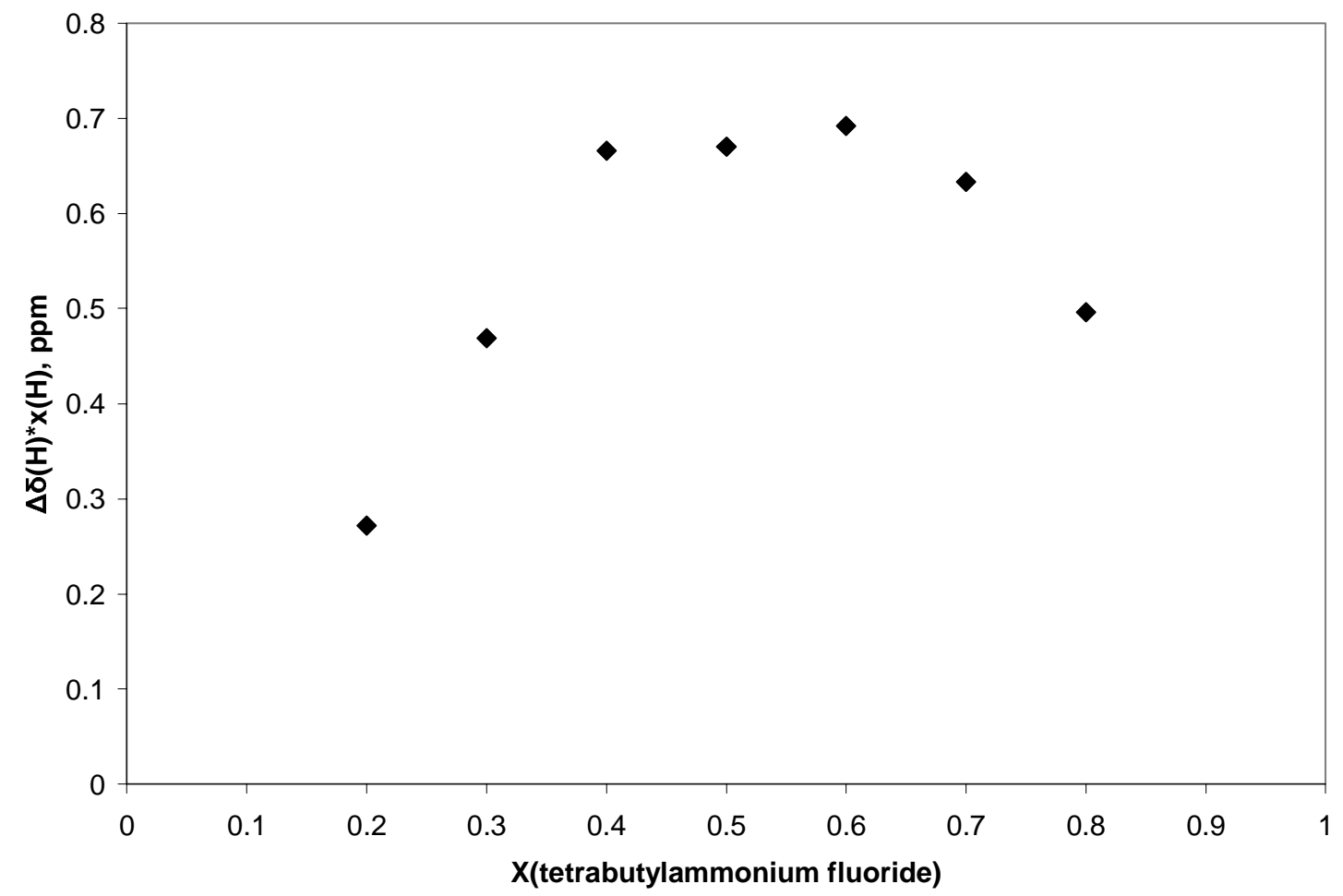

Figure S9. Job's plot of 1 and tetrabutylammonium fluoride, based on the chemical shift of the amide protons, showing 1:1 stoichiometry of the reaction of the product of [1+1] condensation with $F^{-}$. 


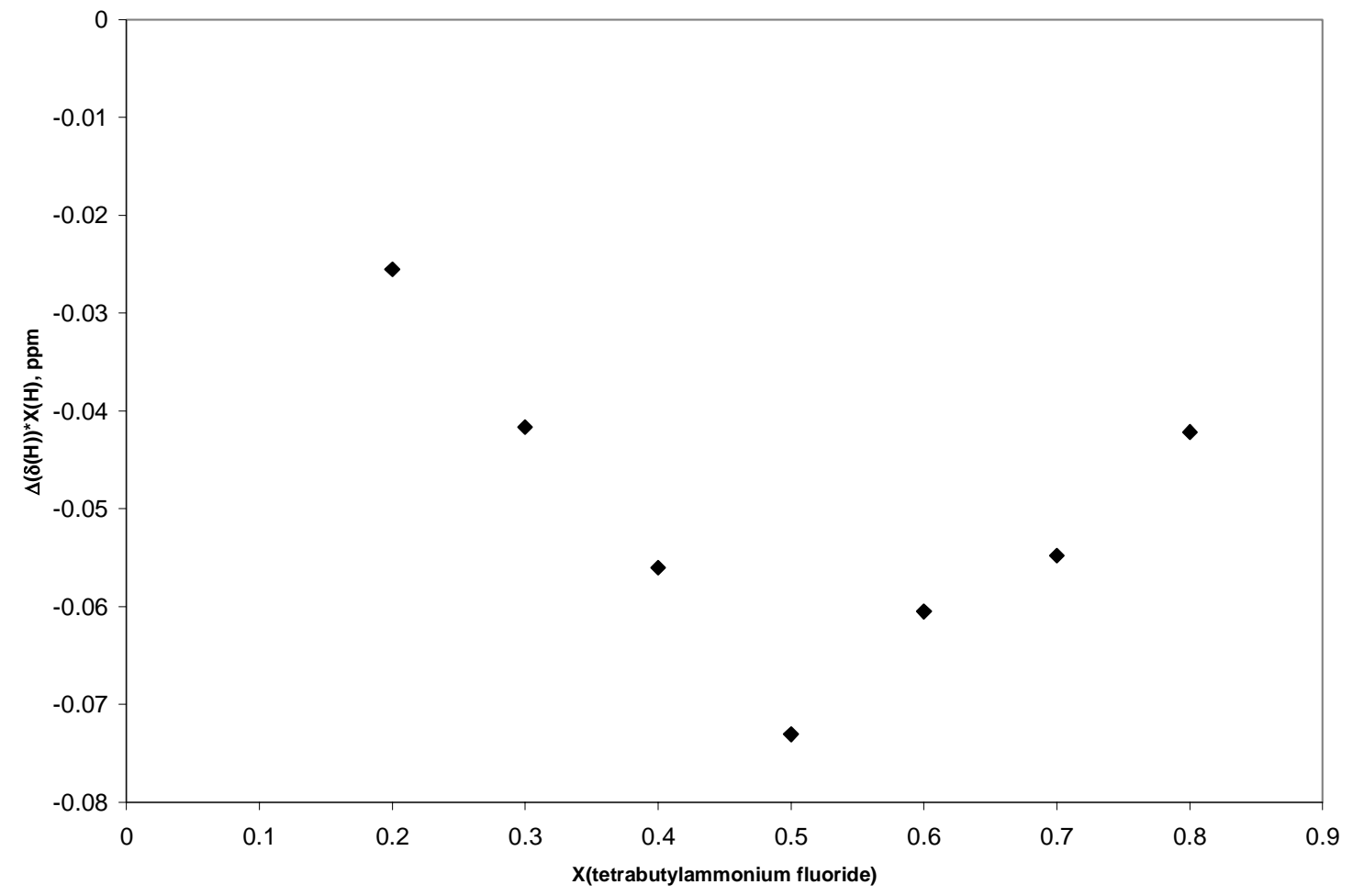

Figure S10. Job's plot of 1 and tetrabutylammonium fluoride, based on the chemical shifts of the $\gamma-H$ in the pyridine ring, showing 1:1 stoichiometry of the reaction of the product of [1+1] condensation with $\mathbf{F}^{-}$. 


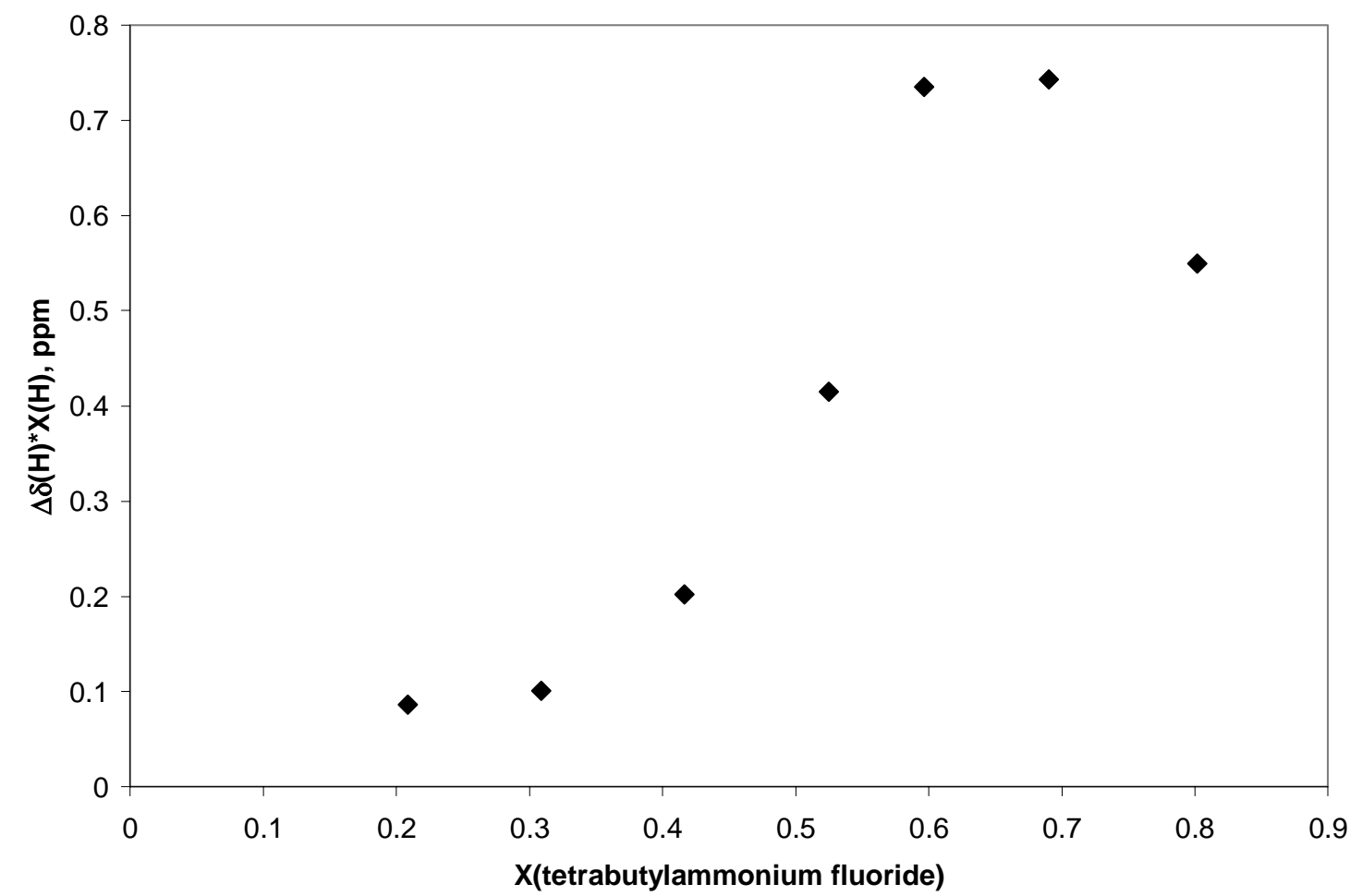

Figure S11. Job's plot of 4 and tetrabutylammonium fluoride, showing 1:2 stoichiometry of the reaction of the product of $[2+2]$ condensation with $F^{-}$. 


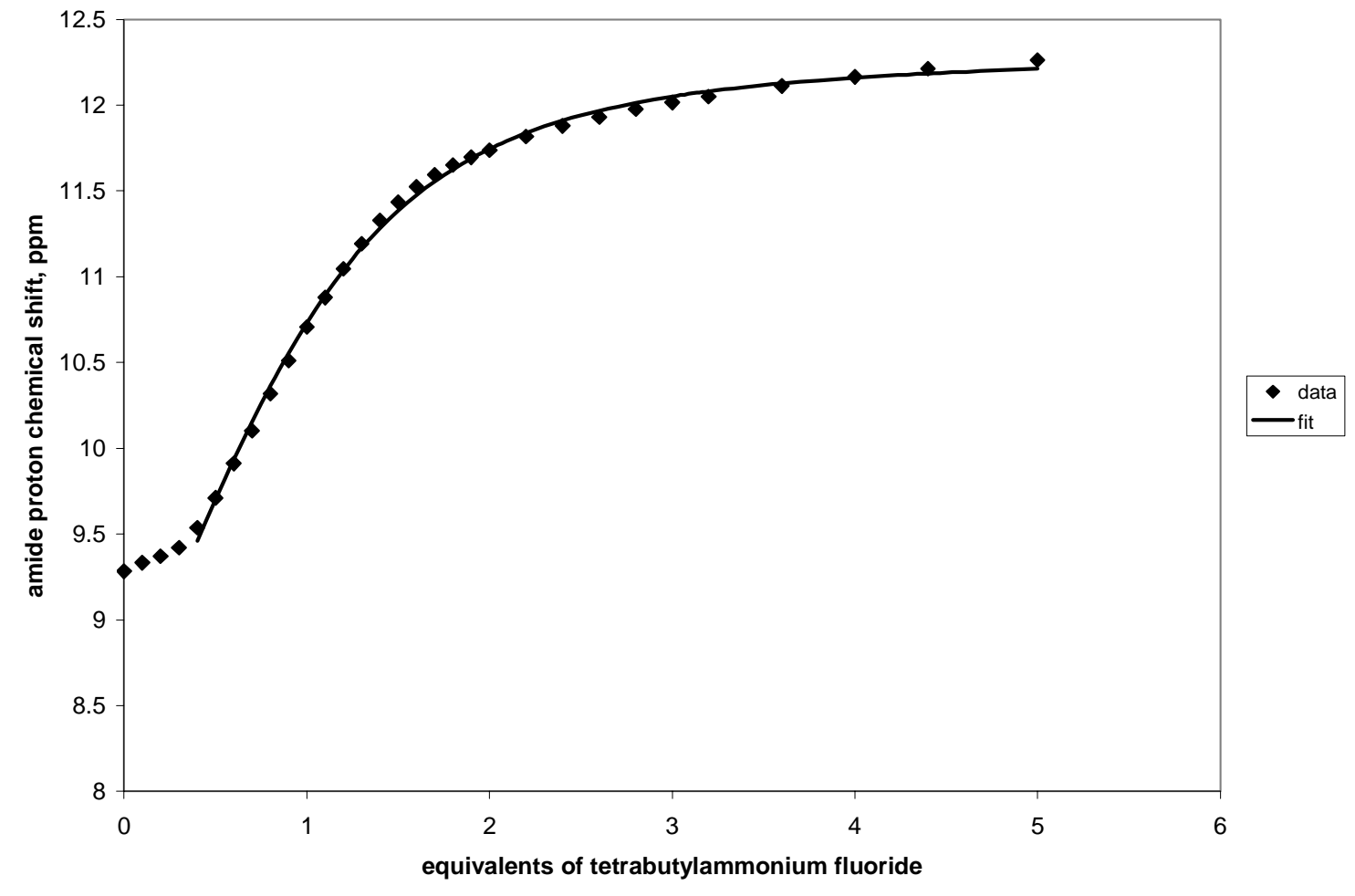

Figure S12. Titration curve of 4 with tetrabutylammonium fluoride at constant water concentration of $250 \mathrm{mM}$ using 1:2 model. Binding parameters determined by program Wineqnmr are $K_{1}=$ $4(7) \cdot 10^{3} M^{-1}, K_{2}=3(5) \cdot 10^{2} M^{-1}, R=0.31 \%$. 


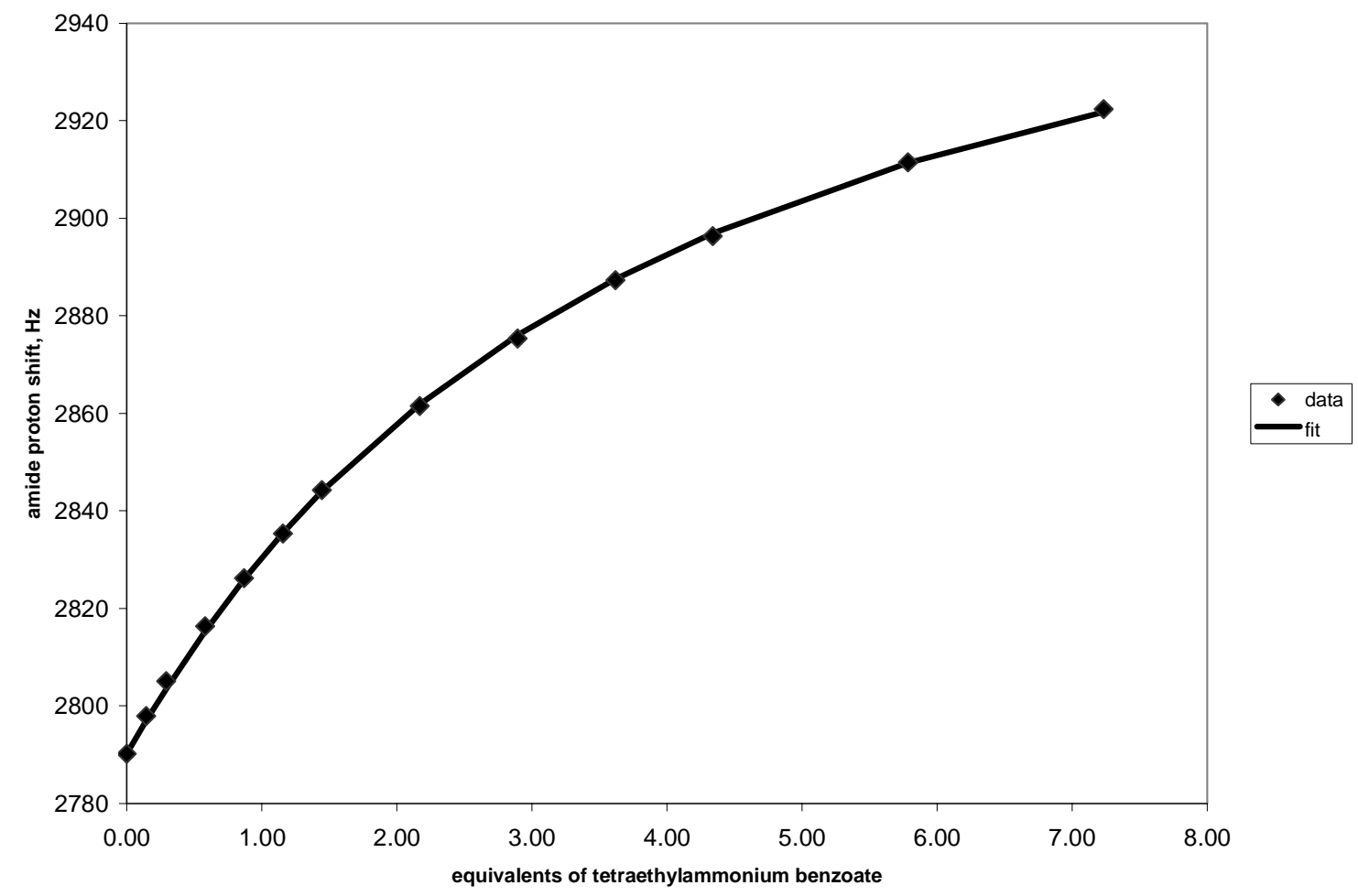

Figure S13. Titration curve of 4 with tetraethylammonium benzoate. Binding parameters determined by program Wineqnmr are $\delta\left(4 \cdot \mathrm{BzO}^{-}\right)=3055(4) \mathrm{Hz}$, association constant $\mathrm{K}=31.9(9) \mathrm{M}^{-1}, \mathrm{R}=\mathbf{0 . 0 1 \%}$. 


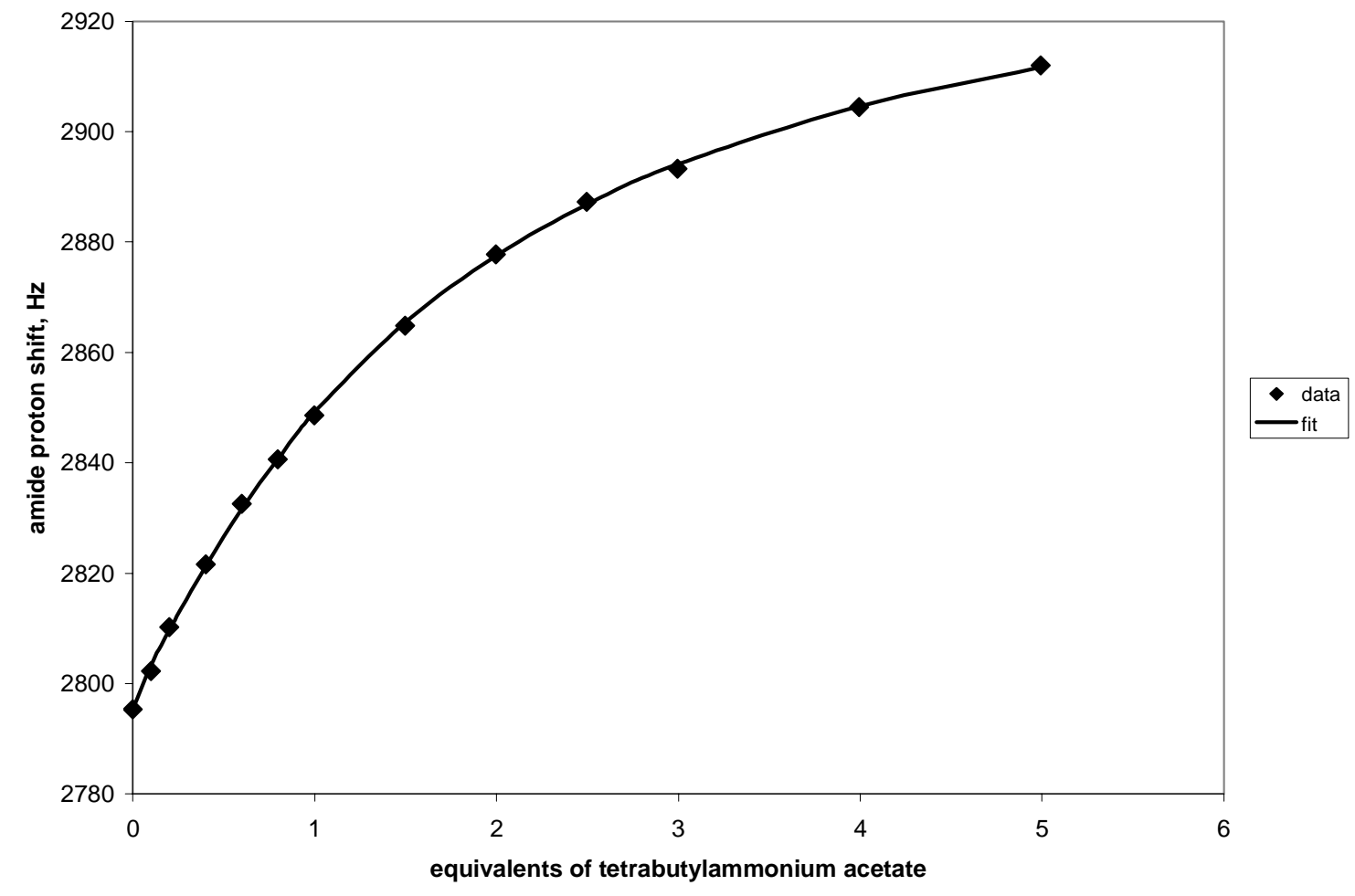

Figure S14. Titration curve of 4 with tetrabutylammonium acetate. Binding parameters determined by program Wineqnmr are $\delta\left(4 \cdot \mathrm{AcO}^{-}\right)=2969(3) \mathrm{Hz}$, association constant $\mathrm{K}=67(3) \mathrm{M}^{-1}, \mathrm{R}=0.02 \%$. 


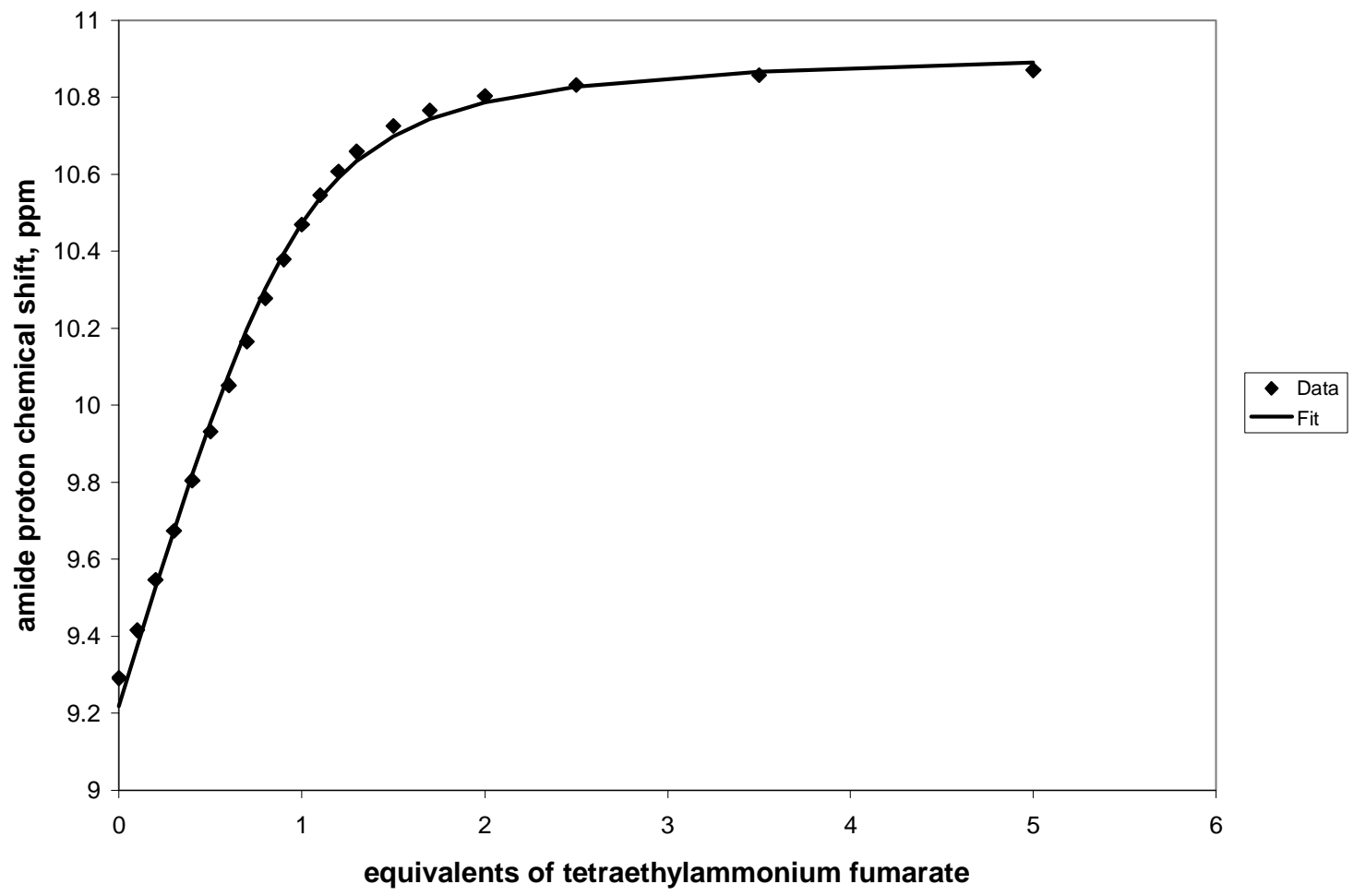

Figure S15. Titration curve of 4 with tetraethylammonium fumarate. Binding parameters determined by program Wineqnmr are $\delta(1 \cdot f u m a r a t e)=3288(6) \mathrm{Hz}$, association constant $\mathrm{K}=$ 1.1(1) $\cdot 10^{3} \mathrm{M}^{-1}, \mathrm{R}=\mathbf{0 . 2 0} \%$. 


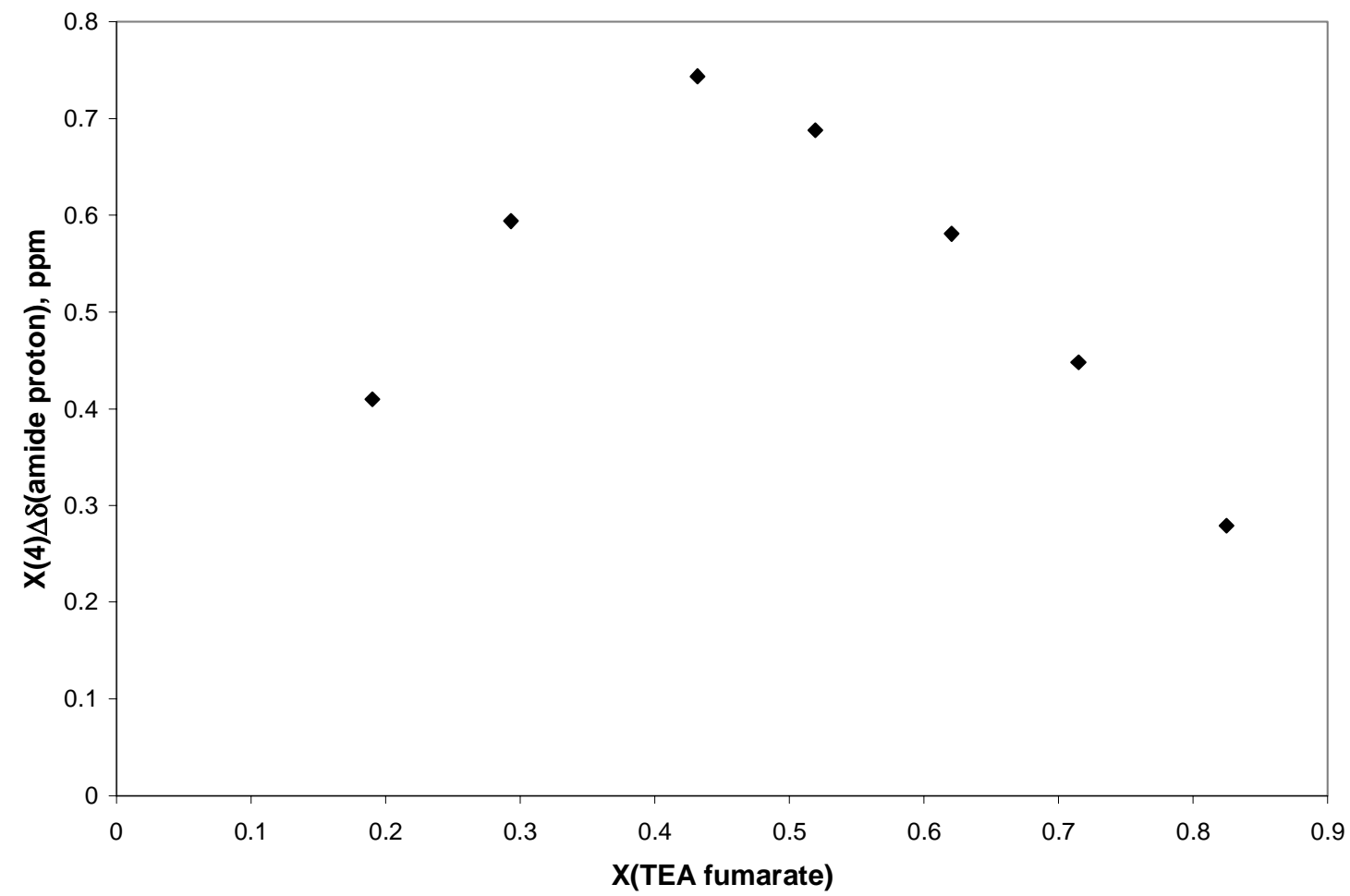

Figure S16. Job's plot of 4 and tetraethylammonium fumarate, showing 1:1 stoichiometry of the reaction of the product of $[2+2]$ condensation with fumarate. 


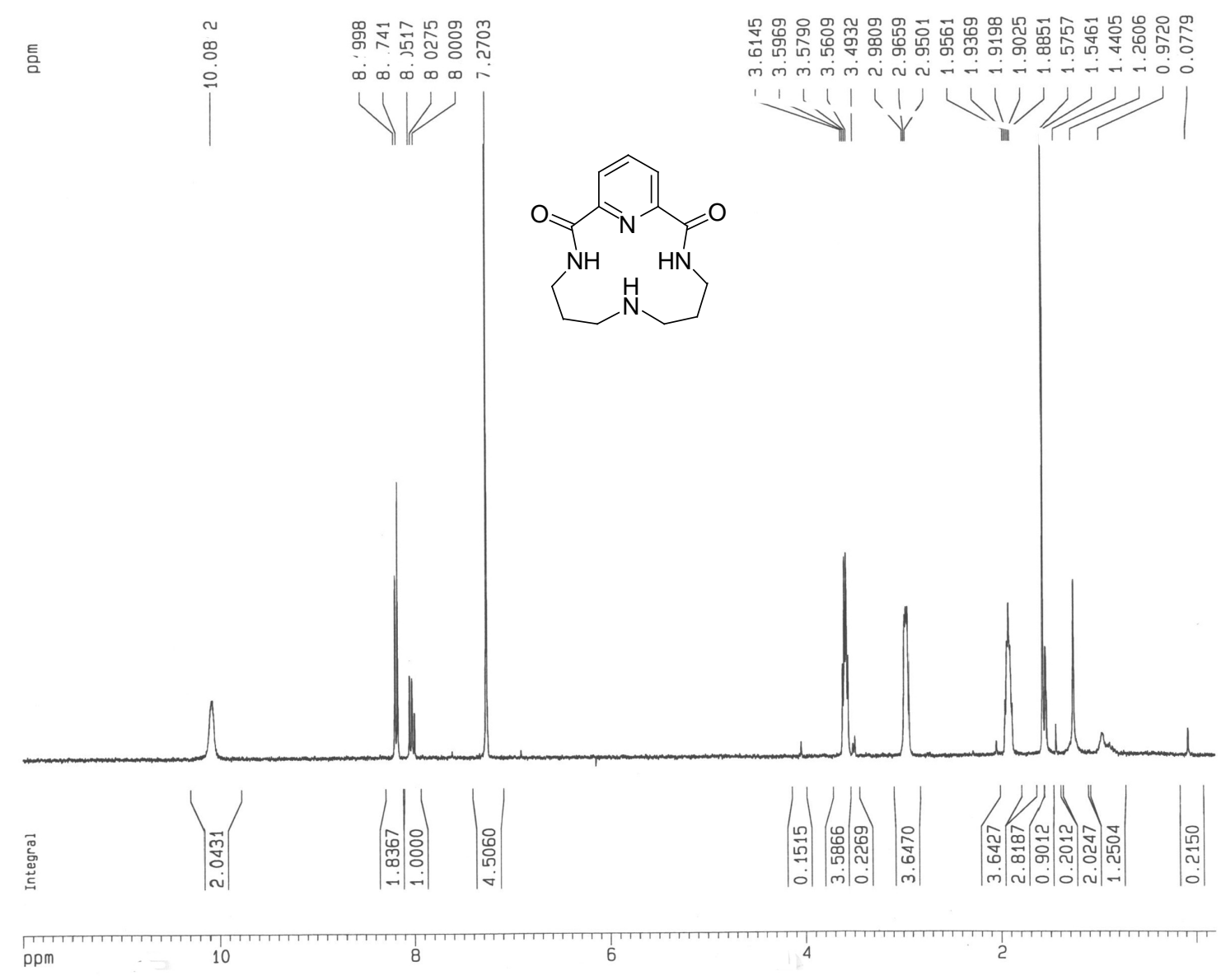

Figure S17. ${ }^{1} \mathrm{H}$ NMR spectrum (300 MHz) of $2 \mathrm{a}$ in $\mathrm{CDCl}_{3}$. 


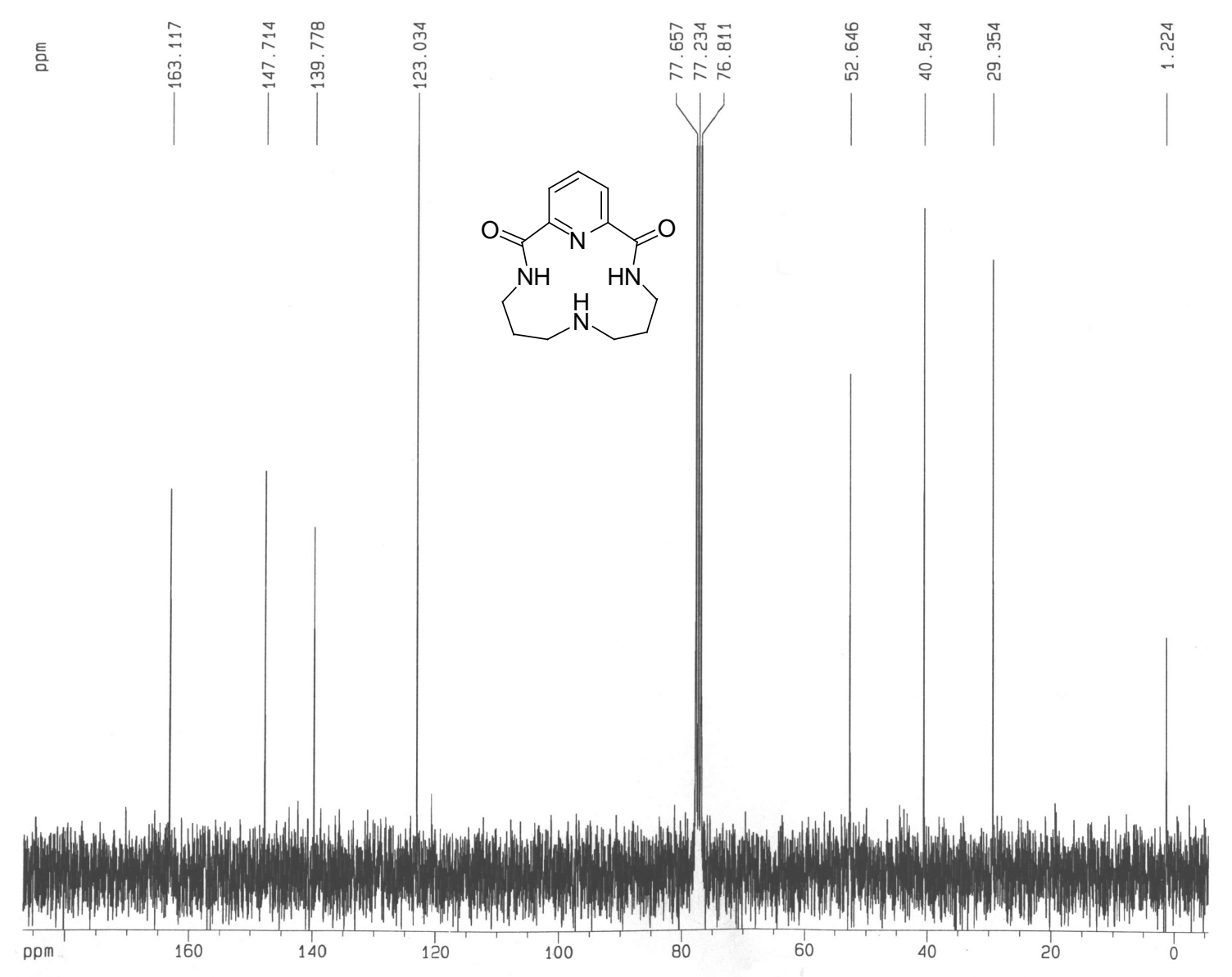

Figure S18. ${ }^{13} \mathrm{C}$ NMR spectrum (75 MHz) of $2 \mathrm{a}$ in $\mathrm{CDCl}_{3}$. 


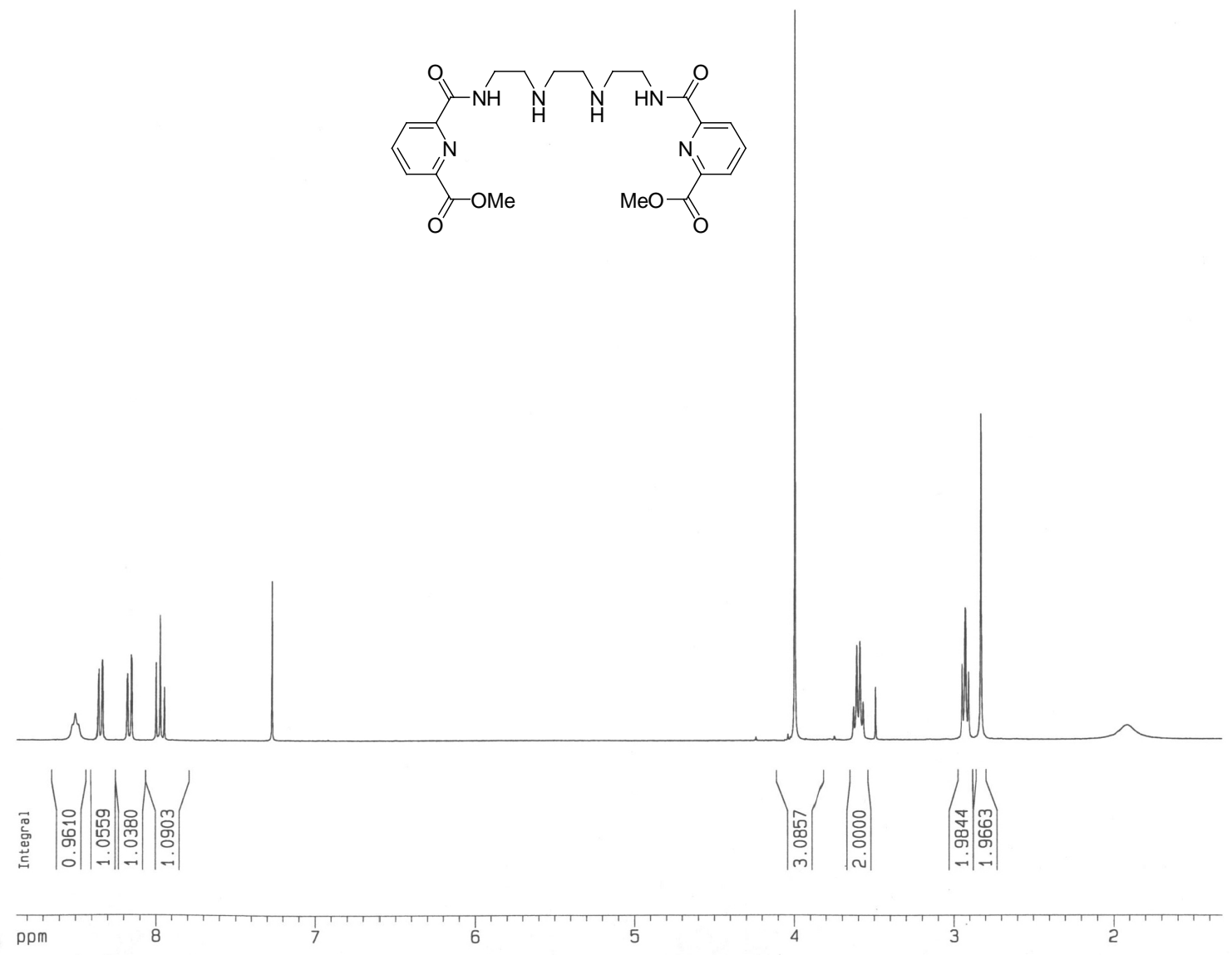

Figure S19. ${ }^{1} \mathrm{H}$ NMR spectrum (300 $\left.\mathrm{MHz}\right)$ of 3 in $\mathrm{CDCl}_{3}$. 


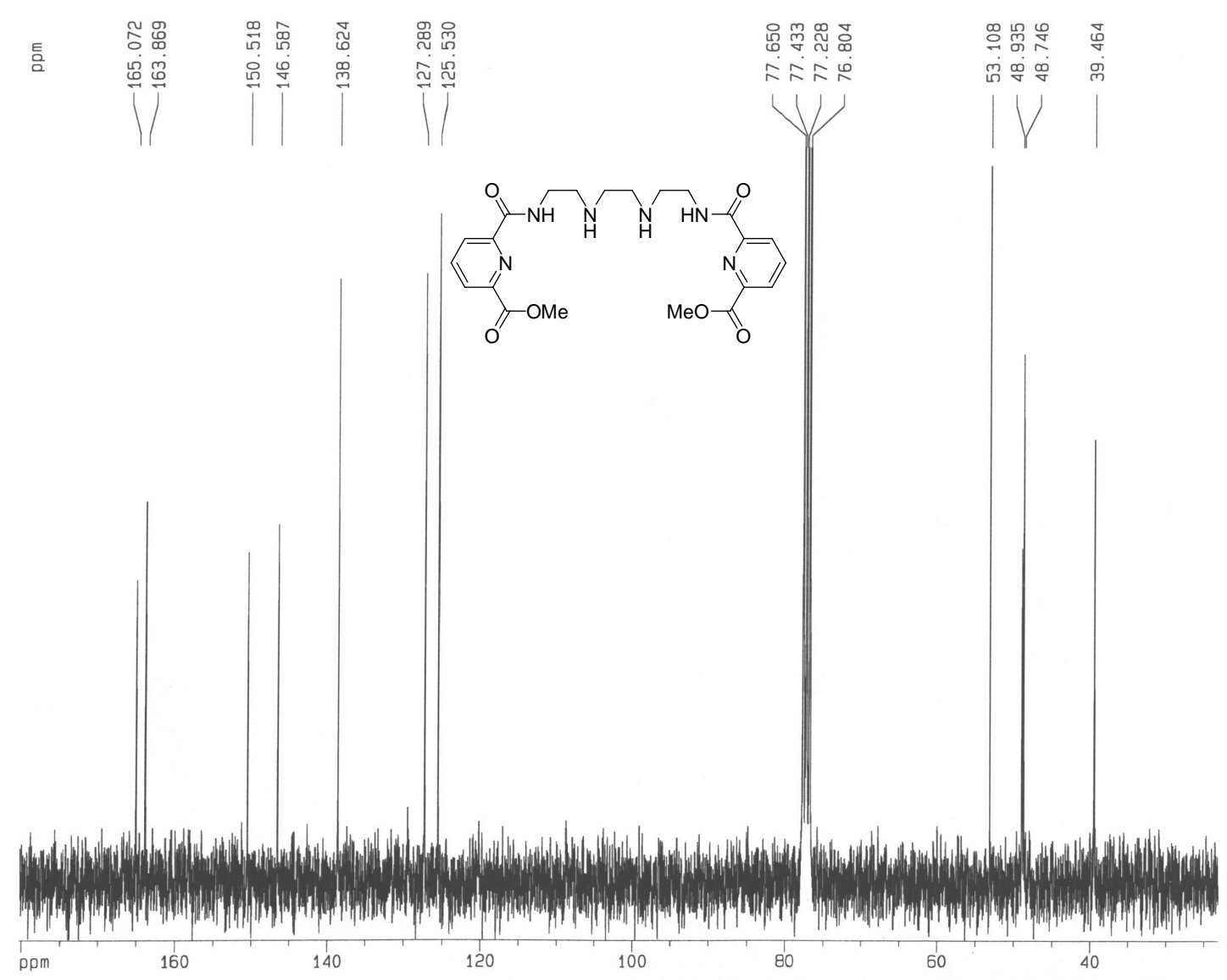

Figure S20. ${ }^{13} \mathrm{C}$ NMR spectrum (75 $\mathrm{MHz}$ ) of 3 in $\mathrm{CDCl}_{3}$. 


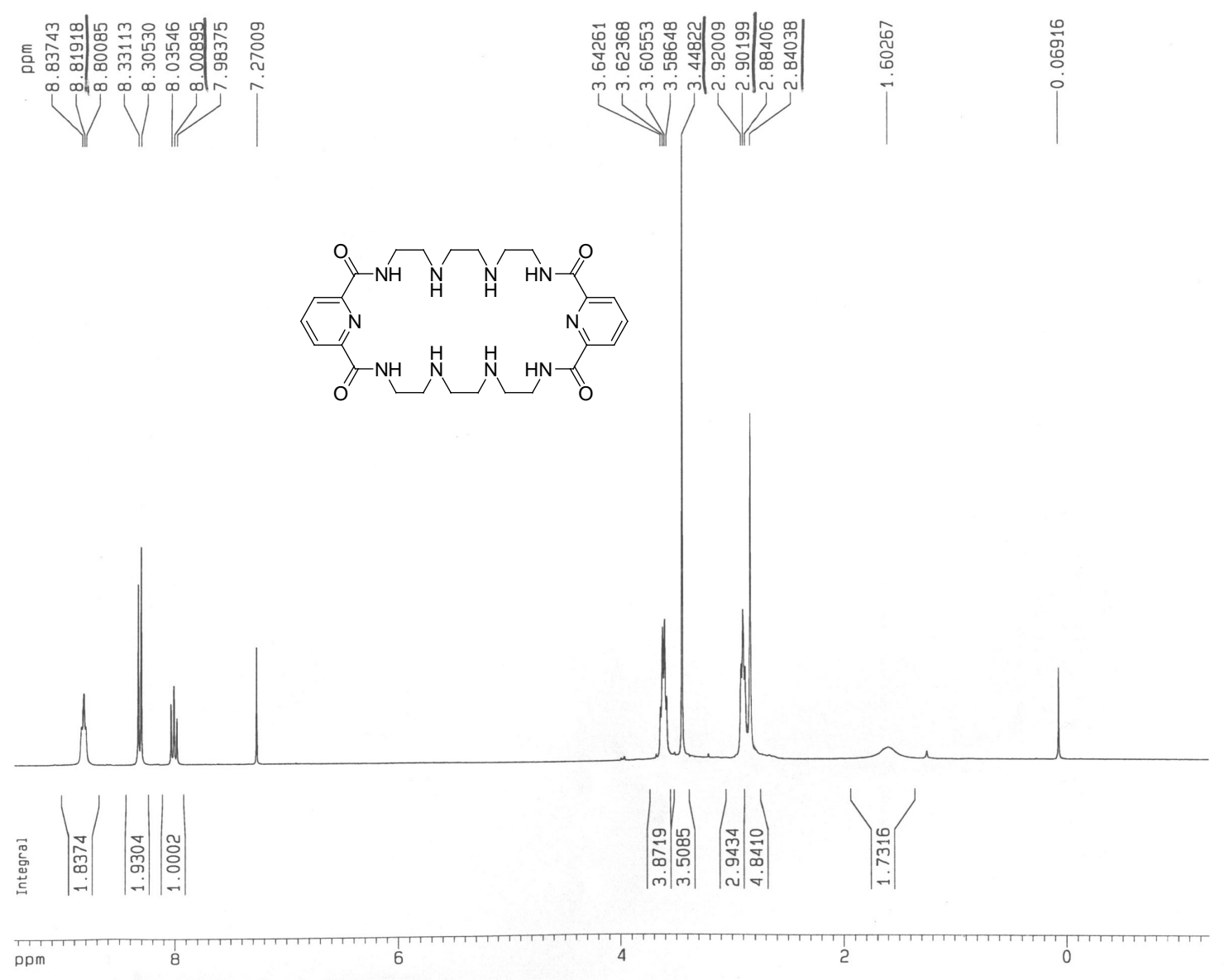

Figure S21. ${ }^{1} \mathrm{H}$ NMR spectrum (300 MHz) of 4 in $\mathrm{CDCl}_{3}$. 


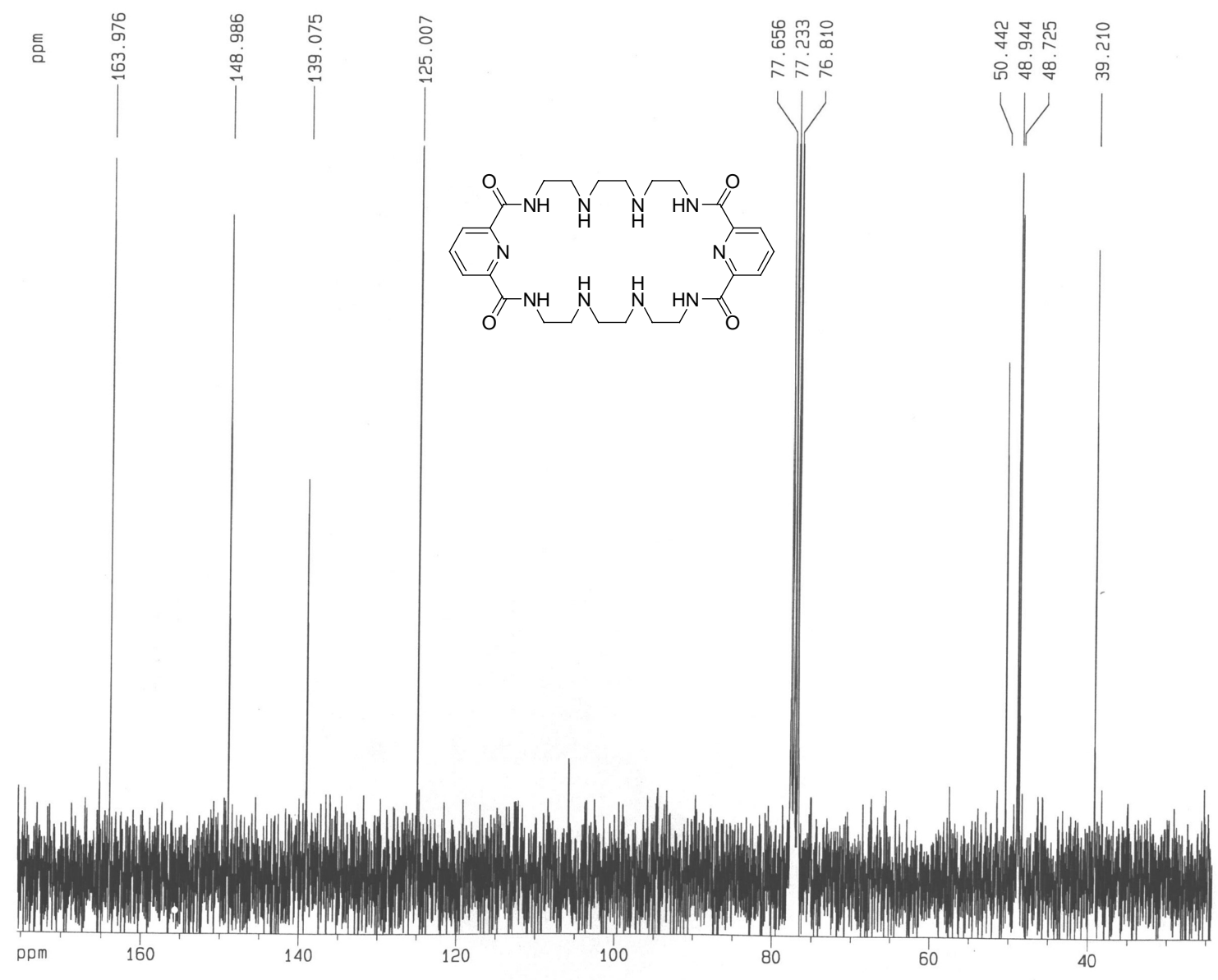

Figure S22. ${ }^{13} \mathrm{C}$ NMR spectrum (75 MHz) of 4 in $\mathrm{CDCl}_{3}$. 